\title{
Hazards and Crisis: A Political Economy of Drought and Famine in Northern Nigeria
}

\author{
Michael Watts
}

1983. Antipode 15 (1), 24-34. ${ }^{1}$

\section{Introduction}

During the early 1970s much of the Sahel and northern Sudanic savannas of West Africa was gripped by a devastating famine which had its origins in a run of drought years in the late 1960s. Prior to the exposure of widespread starvation and human suffering throughout Sahelia, both the academic and popular presses paid scant attention to the Sahel's existence. Since 1974, however, the arid and semi-arid lands have assumed [some] popularity, if not notoriety, including an appearance on the cover of Time magazine under the dubious title of "creeping deserts." In fact, the Sahel famine in particular has gained a sort of textbook notoriety and is usually invoked as an archetypical example of poor land use, desertification, local or global climatic change, [...] population pressure, or life boat ethics in practice. The Sahel has even entered the heady realms of high culture for John Updike's witty novel, The Coup, based on the demise of the Kingdom of Kush - "land of delectable, delicate emptiness" - [and] clearly modeled after the Sahelian states. In addition there has been the commitment of a massive amount of foreign aid ( $\$ 10$ billion by the Club du Sahel); and political pressure from the Sahelian States themselves prompted the United Nations General Assembly to confront the global problem of desertification, from which emerged an International Conference convened in Nairobi during 1977. Yet, despite the resultant proliferation of Sahelian and Arid Lands Institutes, the profusion of rather ephemeral research organizations, multi-volume studies by USAID on long-

${ }^{1}$ Reprinted with permission from Richard Peet [Editors' note: references are missing in the latter half of the original paper]. 
term development strategies for the Sahel (in which geographers have been heavily involved), and even a pledge from Henry Kissinger to "roll back the desert," all is not well. During the summer of 1978, the French Minister of Cooperation, Mr. Galley, claimed that a calamity of the magnitude of 1972-74 throughout much of the desert edge could only be averted through the astronomical amount of 750,000 tons of immediate food relief. The Director of FAO, in a more sanguine mood, put the figure at 450,000 tons (Harriss, 1978; Watts, 1978). Furthermore, virtually every harvest period brings a new spate of food aid requests and morbid projection of [thickened] gloom.

Not unrelated has been the emergence of a substantial literature which deals with the consequences of the famine on the social fabric of Sudano-Sahelian societies (Berg, 1975; Faulkingham, 1974; Horowitz, 1976; Mortimore, 1973; Sawadago, 1975; Seiffer, 1974). Perhaps inevitably, in view of [...] pastoral modes of livelihood and the mystique of the Tuareg blue-men, much of this research effort has concentrated on the deterioration and demise of traditional institutions and cultural practices associated with the pastoral economy. While the disruption of the livestock sector was unquestionably profound - although not new - there is a strong implication in much of the recent work that the drought undermined the institutional base of these historic societies (Lofchie, 1975). This preoccupation with pastoralism, and with what has been seen by some as "savage anthropology," has been accompanied by a lack of attention to the agricultural economy of the semi-arid zones, to the human ecology of peasant farming communities. Indeed, there has been a tacit assumption that Sahelian agriculture showed much more resiliency than the pastoral sector; as Dyson put it, "it may be easy for the farmers to rebuild their lives" (Dyson-Hudson, 1978, 136). In view of the slight empirical work on farming communities generally in the northern savannas, and particularly under drought-famine conditions, this sort of surmise must remain highly speculative.

In spite of enormous post-famine expenditure on "reconstruction" and "development" throughout the semi-arid lands of West-Africa, it is clear that the peasant economy, if intact, is far from healthy. This "morbidity" is lent a measure of urgency by the current structural crisis in many of West African food economies. The stagnation of food production in Nigeria is particularly apposite in this respect, although in this case Nigeria has fortunately benefited from a massive increase in oil revenues in the wake of a spiraling food import bill. Prior to the oil boom, Nigeria's traditional agricultural exports - cocoa, groundnuts and palm produce - accounted for the overwhelming proportion of foreign exchange earnings. By 1977 they accounted for less than $10 \%$ of Nigeria's non-domestic revenues and only cocoa has managed to survive as a viable economic export. Furthermore, the devastation of the export crop economy has been mirrored by an uninviting climate for the domestic foodstuffs 
producer. An overvalued Naira ${ }^{2}$ permitted low domestic prices for imported consumer goods and foodstuffs. For commodities such as rice, this has meant the under-pricing of locally grown varieties by foreign imports. White bread, constituted almost entirely from cheap imported wheat, is rapidly becoming a staple of the urban poor, displacing the traditional sorghums and millets. The import of staples rose dramatically from 32 million in 1974 to 1.5 billion during 1980. Domestic food prices rose from a base of 100 in 1970 to 490 in 1977 (see Freund, 1978). Projected food deficits are equally bleak.

The general problem of food and hunger in drought-prone northern Nigeria is the subject of this paper. The emphasis on food production and drought is a particularly legitimate realm for geographic research, relating to work on [People]Environment relations, and to natural hazards and cultural ecological research. [...]

In the process of examining the changing character of food production, and environmental risk in northern Nigeria, however, I will emphasize that both hazards research and cultural ecology are sadly lacking and need to be placed in the wider context of the political economy of social systems and specifically the manner in which social formations reproduce themselves. These geographic approaches have suffered from, on the one hand, a profound ahistoricism and, on the other, an inability to relate "adaptive behavior" to the wider socio-economic context in which it is grounded. $[\ldots][\mathrm{T}]$ hese weaknesses $[\ldots]$ are $[\ldots]$ pernicious in human ecology where change is often treated as "disturbance;" in this respect it is parallel to ecology in its preoccupation, until very recently, with stasis and equilibria. It is as though the environment is assumed to somehow determine the rules of behavior such that once a production system is adopted the intellectual problem simply becomes one of "adaptive" response to environmental signals. But humans clearly live not only in an environment constituted by natural processes, but also in one of their own making, constituted by human practice, and subject to ongoing change and historical transformation.

Recently attempts have been made to overcome these shortcomings; Brookfield and Kirkby $(1974,4)$ have emphasized the importance of time and changes of scale in the process by which low risk, autarkic communities are subsumed by larger economic system, which they call system capture and enlargement ${ }^{3}$. Clarke has also examined what he calls "the changing structure of permanence," that is the loss of autonomy by local systems as they become part of a coherent and highly integrated global networks:

\footnotetext{
${ }^{2}$ Naira (\#) is the official Nigerian currency. $1=$ [US]\$0.85. [Editors' Note: In $2008 \# 1$ is worth less than one US cent].

${ }^{3}$ The same point has been made by a number of scholars, but particularly Bennet (1976).
} 
As society and economy are enlarged in the course of development, as communities trade autarky for access to a wider range of goods and services, new and coarser patterns of resource valuation and selection replace old, finer patterns. Specialization replaces diversity; economic risk is added to natural risk (Clarke, 1977, 374).

Grossman's (1979) recent work on coffee and cattle in the Papua New Guinea Highlands is one of the first attempts to examine empirically this changing structure of permanence. He explores the impact of cash-earning activities on the natural environment, the subsistence system, and the structure of social relationships through an uneasy marriage between cultural ecology and economic development. While this genre of work, including that of Nietschmann (1973) among the Miskito Indians, is in some respects akin to what I call political economy, it often fails to specify the structure of the entire productive system. This is true both of the self-sufficient internally regulated systems on the one hand, and of the externally dependent and controlled monetary market systems on the other. The use of ambiguous terms as "subsistence system" and "cash economy" is indicative of the lack of specificity. In sum, in this genre of work there has been firstly an overemphasis on exchange and its role in the linkage of two apparently contradictory productive systems; cash figures prominently in these discussions although money per se conveys nothing of the logic of the economic system itself. And secondly, while considerable attention has been given to production, the priority has been on the operational attribute of productive systems, particularly subsistence, which can be measured as inputs (labor input, caloric expenditure) and outputs (production expressed in monetary or calorific units).

Of course this type of work has yielded some excellent and valuable information, not least on the implications of economic change on local regulatory autonomy and processes of ecological degradation. What is lacking, however, in an analysis of the qualitative aspects of the entire mode of production. As a consequence, the "external" system is never adequately specified and the contrast between the subsistence and cash economies appears idealized, if not Rousseauian; co-operation versus individualism, sufficiency versus profit, and so on. This seems to have reached its apotheosis in Clarke's populism which banishes the ogre to place of "development" forever and apparently wishes to place Melanesian communities in some sort of historical deep freeze. A political economic analysis at least broadens our horizon; as Cook puts it:

Nevertheless, it is important not to allow an empiricist concern for operationalization to eliminate a consideration of fundamental issues of political economic analysis. From this latter perspective, the production focus dovetails directly with problems of access to and/or control over means of production in a given society is allocated among various groups within its population. With this exception of certain simple bands or tribal societies, this kind of inquiry inevitably leads to a study of the 
political power structure and social ranking or stratification (Cook, 1975, $41)$.

The overriding concern with production in its entirety is central to political economy, for production provides the processual link between economy and environment (the appropriation of nature) and between economy and the sociocultural system as a whole. It is here that Marx's contribution is indispensable for what Grossman calls the "cultural ecology of development"; this particular synthesis of economy and ecology, is nothing less that an analysis of the transformation of modes of production.

... traditional social structures are breaking down everywhere under the impact of the new economy and traditional precapitalist values are slowly disappearing ... All over the world, finally, we see the disappearance of integrative mechanisms based on kinship, locality and primary relations and the rise of the new social mechanisms of integration, based on the market ... (Stavenhagen, 1975, 67).

I shall argue in fact that the concept of mode of production is central to an understanding of the changing structure of permanence of which Clarke speaks. In the case of northern Nigeria, I shall endeavor to show that the integration of pre-capitalist forms of production into a global capitalist system, largely under the aegis of the colonial state, explains the changing character of peasant production and in particular the current vulnerability of rural producers to environmental hazards for which they are conceptually prepared. It is precisely the inability of some peasants to respond and hence to reproduce themselves - under conditions of environmental risk that characterizes the transformation of pre-capitalist systems of production in Hausaland and the emergence of new patterns of socio-economic differentiation. In this sense one can legitimately talk of structural maladaptation in a society of petty commodity producers in northern Nigeria.

A political economic approach does not deny the validity of orthodox cultural ecological enquiry. It is obviously legitimate to study [hu]man/land/pig ratios in Melanesia, or labor productivity in peasant differentiation, the genesis of value and so on. Environmental relations are, then, instances of the productive process. In other words, adaptive strategies or coping responses are grounded in the social relations of production in the concrete historical circumstances of the underdeveloped world. As Walker explains:

\{Natural hazards research\} deals with material conditions which leads to exposure to hazards ... \{and hence\} is engaged in the study of natural resources and environment use in general \{and\} calls for a sophisticated analysis of political economy, particularly of development and underdevelopment (Walker, 1979, 7).

From a Marxist viewpoint, adaptive behaviors are elements of what Friedman (1975) calls systems of social reproduction (see also Wisner, 1978). 
From a political-economic perspective, then, an environmental crisis not only probes the darkest corners of environmental relations, but throws into sharp relief the organization and structure of social systems at large. The impact of a drought on human communities affords the social scientist a particular optic through which to view the functioning of the social formation; indeed it was Marc Bloch who observed that:

Just as the progress of a disease shows a doctor the secret life of a body, so to the historian the progress of a great calamity yields valuable information about the nature of the society so stricken (Bloch, cited in Geertz, 1967, i).

In this manner, natural hazards are not really natural for though a drought may be a catalyst or trigger mechanism in the sequence of events which leads to famine conditions, the crisis itself is more a reflection of the ability of the socio-economic system to cope with the unusual harshness of ecological conditions and their effects. To neglect this fact is to resort to a fatalism which sees disasters as metaphysical, as acts of God in which the responsibility is shouldered by Nature; in the process, of course, this misses a major political point. In Nigerian Hausaland, which provides the geographical context of this study, the social, political and economic attributes of food crisis are captured in the paradox that during the famines of the past 70 years it has been the men and women who work the land who have perished for lack of food. Those who died were those who produced.

The crisis created by a famine reveals the workings of the economic and social system and affords an insight into that structural violence which has the effect of denying the poorest ... the right to feed themselves ... The fact that ... the town dwellers can still get something to eat while that country people starve ... is a sign of the power relation between urban and rural populations (Spitz, 1977, 3).

This, I suspect, is what E. P. Thompson (1978) means when he refers to the "crisis of subsistence" as an historical category. [...]

To appropriate the fact that hazards and risk is mediated by the relations of production of the societies affected is simultaneously to recognize that "modernization" or "development" has not necessarily solved the age-old problems of subsistence crisis or vulnerability to environmental threats, and in some cases has actually aggravated them. Indeed an enormous body of literature would suggest that the living conditions of the Third World rural poor have been deteriorated, that colonialism and the expansion of petty commodity production have amplified the riskiness of peasant livelihood. The precariousness of food production systems is reflected in chronic food deficits throughout much of the underdeveloped world, the almost constant threat of famine across vast areas of Africa, and the increasing dependency of underdeveloped countries on food staples imported from the West, particularly the United States. 
In Northern Nigeria, I will argue, food production systems and the socioeconomic context of climatic risk have changed dramatically since the pre-colonial period. These changes were not effected by the evolution of large European estates. ${ }^{4}$ In contrast to the speculations of Marx and Kautsky, the peasantry did not disappear with colonial penetration but, rather, capital changed their conditions of production while maintaining some pre-capitalist characteristics intact. This process of conservation and dissolution, as Bettelheim calls it, was integral to the general process of underdevelopment in Nigeria; as Kay says "Capital created underdevelopment because it did not exploit it enough" (Kay, 1975, x). Subsistence security in Northern Nigeria has been undermined nonetheless and the circuits of food production and exchange altered.

\section{Nigerian Hausaland}

The dynamics and pattern of Nigerian rainfall depend very largely on the movements of two major air masses: the tropical Maritime (mT) and the tropical Continental (cT). The dry north-east trades of the latter emerge from the Saharan massif, while the south-west monsoons of the former are characteristically moisture laden and the harbinger of the rainy season. The broad pattern of precipitation reflects the conjunction of these two air masses, that is, the movement of the intertropical discontinuity (ITD). The ITD is in fact a "quasi-stationary moisture boundary," which Oguntoyinbo and Richards describe as follows:

The surface location of the ITD is often identifies by the surface wind direction and humidity as indicated by the dewpoint. In the moist equatorial air mass the wind has a southerly component ...The drier (cT) ...has a northerly or easterly component and a dewpoint less than $14^{\circ} \mathrm{C}$. The depth of the moisture layer is of the order of 1500-3000 meters during the rainy season ... and under 1500 meters in the dry season (Oguntoyinbo and Richards, 1977, 114).

The advance and retreat of the ITD has a profound influence on the onset and termination of the rains. As its northern apex, the location of ITD is approximately Lat. $20^{\circ} \mathrm{N}$ which it usually attains in August, the southern limit; conversely, in January and February, [it] is approximately $7^{\circ} \mathrm{N}$ Lat.

Like the entire Sudano-Sahelian zone, northern Nigeria experiences a markedly seasonal climatic and ecological regime. A 7-8 month dry period (rani) between October and May, is followed by a short but intense wet season (damana) into which most agricultural activity is concentrated. Precipitation is unimodal in distribution,

\footnotetext{
${ }^{4}$ For a discussion of such changes elsewhere in Africa see Cowen (1976) and Wisner (1978).
} 
peaking during the months of July and August. The mean annual rainfall for the Katsina station over the 1922-1969 period is 29.6 inches [751.8 mm] (standard deviation 4.9 inches [120.1 mm]). The pattern of precipitation is marked by enormous spatio-temporal variation in the onset, distribution and termination of the rains. Since temperatures rarely fall below $42^{\circ} \mathrm{F}\left[5.6^{\circ} \mathrm{C}\right]$, the critical threshold for plant growth, the growing season is contingent upon the distribution of annual rainfall. The predominant aeolian [wind-borne sediment], highly permeable soils arry a large water deficit at the onset of the growing season and cereals are, therefore, dependent on rainfall alone. Distribution and variability of precipitation is thus as important as absolute quantity for Hausa agronomy.

\section{Drought, Risk and Political Economy in the Pre-Colonial Period ${ }^{5}$}

The basic unit of production in the nineteenth century was the household, perhaps embracing sons, clients, and slaves in an extended domestic structure in which the householder organized production and distribution and paid taxation. Households were often subsumed in communities controlled through the agency of village heads whose responsibility extended to land sales and village adjudication. A proportion of the peasant surplus was expropriated by a ruling class in the form of [...] labor, grains, or cash. The office holders had tenure over "fiefs" given by the Emir, though they

usually resided on private estates worked by slave, client and hired labor; they could also demand corvee labor from villages within their territorial jurisdiction. Slave labor, although crucial to the functioning of the large estates operated by the ruling class, was not a dominant characteristic of the productive system. Craft production and petty commodity production generally, emanating from within the household structure, was conversely a widespread phenomenon through Hausaland. The State controlled the means of coercion, provided protection for the peasantry and traveling merchants, organized large-scale labor projects and acted as a guarantor in times of needs. Within this tributary formation, subsistence risk is historically specific since, as I will show, peasant reproduction in the face of hazardous climatic environment was secured through the network of horizontal and vertical relationships and reciprocities which were embedded in the social relations of production. In this regard the Sokoto Caliphate - the entire state structure which subsumed Hausaland - was hardly a "natural economy"; it possessed its own class contradictions, methods of surplus extraction and ideological hegemony, while commodity production existed in some form. Nevertheless, it was the production of use-value that predominated.

It is perhaps worth reiterating that contrary to prevailing opinion during the Sahelian famine of 1970-74, drought and famine are not new phenomena to the desert edge. Rather they are recursive and the historical landscape of northern Nigeria is

\footnotetext{
${ }^{5}$ This section draws on Hill (1977), Usman (1974), and Freund and Shenton (1978, 8-10).
} 
littered with references to the great famines (babban yunwa) of the past. The dialectic of "feast and famine" is a recurrent motif in Hausa history and the intense hungers of the precolonial period, which often embraced the vast tracts throughout the savannas, were usually named and imbued with a sort of environmental personality. The recursivity of drought and food shortage is reflected in the cognitive characteristics of both phenomena in the Hausa world view. Not only is there a complex and subtle terminology, a lexicon of sorts, associated with rainfall variability and oscillations in food supply, but drought-famine is embodied in the most significant cultural and artistic forms such as praise epithets (kirarai), folktales (tsatsunyoyi), fables (almara) and anecdotes (labarunda). The cognitive position of famine is, in an oblique way, not unlike the Great Depression in the West for those who lived through it.

Table 1. Subsistence Security and Adaptive Structure in the Pre Colonial Period

\begin{tabular}{|c|c|c|c|}
\hline $\begin{array}{l}\text { Subsistence } \\
\text { Security } \\
\text { Response Level }\end{array}$ & Safety-First & Norm of Reciprocity & Moral Economy \\
\hline $\begin{array}{l}\text { Agronomic/ } \\
\text { Domestic }\end{array}$ & $\begin{array}{l}\text { - Agronomic risk } \\
\text { aversion, intercropping } \\
\text { - Crop rotation, moisture } \\
\text { preservation } \\
\text { - Crop experimentation } \\
\text { - Exploitation of local } \\
\text { environment } \\
\text { - Secondary resources } \\
\text { - Domestic support }\end{array}$ & & \\
\hline Community & & $\begin{array}{l}\text { - Inter-family risk sharing } \\
\text { - Extended kin groups } \\
\text { - Reciprocity } \\
\text { - Redistribution to the } \\
\text { poor } \\
\text { - Storage, ritual sanction } \\
\text { - Anti-famine institutions } \\
\text { - Patron-client relations } \\
\text { - Communal work groups }\end{array}$ & \\
\hline Regional/State & & & $\begin{array}{l}\text { - Regional, ecological } \\
\text { interdependence } \\
\text { between desert edge } \\
\text { and savannas } \\
\text { - Local, regional trade } \\
\text { in foodstuffs } \\
\text { - Role of the State } \\
\text { (central granaries, tax } \\
\text { policy) }\end{array}$ \\
\hline
\end{tabular}


In light of the recursiveness of rainfall and harvest variability, it is to be expected that rural communities were geared to environmental risk, and possessed adaptive flexibility and adjustment capability with respect to drought and oscillations in the availability of food. Scott has suggested that this adaptive flexibility, the capacity to cope in a risky environment, is intrinsic to peasant communities generally and that pre-capitalist societies were to a large degree organized around the problem of risk and the guarantee of a minimal subsistence, a margin of security (Popkin, 1979; Scott, 1976). Scott calls this margin a subsistence ethic which can be decomposed into three dimensions: a general proclivity toward risk aversion in agriculture ("safety first"), a tendency toward mutual support ("the norm of reciprocity"), and an expectation of minimal State support ("the moral economy"). These dimensions correspond to three levels of response which I have identified for nineteenth century Hausaland; that is, three systemic levels of adaptive capability which could, to a greater or lesser degree, accommodate the stresses imposed by drought and/or food shortage. A composite picture of these levels in conjunction with Scott's subsistence ethic is given in Table 1. A measure of the collective welfare which was presupposed by the moral economy of the Hausa peasantry can be estimated from the following outlines of the pre-colonial adaptations to drought and food shortage.

\section{Response to Drought}

The existence of a precarious environment has given rise in many peasant societies to a subsistence ethic predicated upon a safety-first or risk aversion principle. In practice this might involve a plethora of locally adapted cereal varieties, a preference for the consumable versus the marketable, or reliance on historically established planting and intercropping strategies. Throughout much of nineteenth century Hausaland, the production conformed in large measure to this rough archetype. The basic agronomic strategy consisted of the intercropping of sorghums and millets, each characterized by contrasting moisture requirements. This complimentarity was supported, in some locations at least, by a complex orchestration of microenvironments involving variations in spacing, moisture availability, and soil type, all of which were conjoined through complicated sequential patterns of decision-making dependent upon the onset, character, and duration of the rains. Such adaptive programs could be supplemented by other drought resistant crops, like cassava, or the resort to foraging, collecting and hunting. In this way, agricultural diversity and agronomic variation bred a systematic stability.

\section{Response to Food Shortage}

The subsistence ethic was also expressed through social activities and institutions which functioned, among other things, as guarantors of a minimal food supply. Shortage was, of course, fundamental to the preservation of a measure of self- 
sufficiency. This permitted the long term constitution of reserves sufficient to cover seed requirements and grain during the period of pre-harvest hunger. The closure of household granaries during the post harvest period often corresponded with the departure of adult males on dry season migration frequently as corvée labor on State sponsored (defense) projects. During the wet season itself, when seasonal food shortages peaked, hardship could be partially alleviated by participation in communal work parties and short-distance migration, making use of the variation in the onset of the rains (and hence in the timing of planting, weeding, and harvest). Central to the subsistence ethic, however, and to the moral economy in general, was the "logic of gift"; the reciprocal and redistributive qualities which bind the peasant social fabrics, and by which the possibility of accumulation finds an institutional obligation to redistribute.

The inflated emphasis on the role of kinship and descent grouping generally is one way in which risks are diffused and collective security instituted. Among the nonMuslim Hausa, the descent group refereed to as the clan segment functions to this end:

\{The segment\} has but one function: when the grain stores of one household are exhausted, its head may borrow grain from another \{segment\} household and repay the grain at harvest without interest (Faulkingham, 1971, 123).

At an ideological level, the redistributive ethic was reiterated through Muslim dogma in which gift-giving is obligatory for the rich and office-holders. At another level, other formal institutional mechanisms incumbent upon the ruling elite served to free resources from the rich to go to the peasantry. The communal work group was a case in point - foodstuffs being released during the critical pre-harvest period (Raulin, 1964, 71). A more elaborate instance was the institution of sarkin noma (literally, king of farming), elected by virtue of his capacity to produce an excess of 1,000 bundles of grain (Nicolas, 1966). In essence, this is an attenuated variant of the North American "potlatch" in which prestige is accrued thought the ceremonial distribution of resources. The office of Sarkin noma entails on the one hand a redistribution of foodstuffs through the harvest festival and on the other it is: "The ultimate defense against famine: when the grain in any gida is exhausted, the residents may obtain an interest free loan of grain from the S. noma's bins, to be repaid at harvest" (Faulkingham, 1971, 81).

In a society predicated upon an absolute hierarchal segmentation between rulers and ruled, it is hardly surprising that the upper echelon of political authority in nineteenth century Hausaland were expected to act as the ultimate buffers for the village level redistributive operations. The responsibilities and obligation of the village heads were quite clear in this respect and when their capabilities were over-ridden in cases of extreme seasonal hardship, the next level of the hierarchy (the fief holder) was activated. In Katsina Emirate, for example, the district heads often kept grain at several centers throughout their district and frequently in villages where they may have acted as patron to a number of clients. These graduated responses terminated with the State 
structure itself which used the grain tithe for central granaries for organized redistribution during famine periods.

In this fashion, responses to food shortages were graduated with respect to time and depth of commitment. The early responses tended to be shallow and reversible perhaps the sale of livestock or familial loans - and the later ones less flexible, perhaps culminating in widespread dislocation through permanent out migration or even death. All this is not to suggest a [...] pre-capitalist bliss, a glorified peasant life somehow optimally adapted and ultra-stable. This, it seems to me, is a major weakness of the work of Chasin and Franke and Kjekshus [...]. In these works it is easy to forget the obvious limits of pre-capitalist technology, of class relations and surplus extraction, and of extensive slavery. Rather, I suggest that various individual and collective practices, some of which are still extant, permitted a margin of security and dealt with normal agricultural risks. This pantheon of adaptive strategies was, moreover, firmly grounded in the social and economic architecture of the Sokoto Caliphate. Peasant security, and by extension the hazardousness of place, was intricately bound up with the nexus of horizontal and vertical ties which were coterminous with the social relations of production. I shall argue that it was precisely the effect of colonialism and expanded commodity production to sever households from these reciprocal ties for renewal of the means of production and subsistence and hence to magnify their vulnerability to environmental hazards.

\section{Peasant Security, Commodity Production and the Colonial State (1903-1960)}

Colonialism in northern Nigeria was a process of incorporation in which the pre-capitalist forms of production were integrated into a global division of labor. This articulation was principally effected through the colonial triad of taxation, export commodity production, and monetization. Although the colonial leviathan [political state] left peasant producers in the dominant role of merchant capital in Nigeria[, this articulation] progressively transformed the social relations of production. To the extent that pre-capitalist elements in northern Nigeria were eroded by colonial integration, the adaptive capability of Hausa communities and the margin of subsistence security accordingly changed. In the process, peasant producers - particularly the rural poor became less capable of responding to, and coping with, drought and food shortage. Traditional mechanisms and adjustments disappeared, the extension of cash cropping undermined self sufficiency in foodstuffs, a dependence on volatile world commodity prices (for cotton and groundnuts) amplified an already high tax burden and households became increasingly vulnerable to environmental perturbations such as drought or harvest shortfalls. This vulnerability and marginality is highlighted by four major famines which occurred during the colonial period in 1914, 1927, 1942, and 1951. I cannot do justice to the complexity of the process of colonial integration in northern Nigeria, nor its effects on the structure of peasant production, both of which are treated at great length elsewhere. Rather I will sketch some of the pertinent aspects of the changing conditions of food production - particularly the extraction of surplus 
value and the denouement of the moral economy - and draw some tentative links to the increasing hazardousness of peasant livelihood.

The new colonial administration sought through taxation to divert as much of the surplus formerly extracted by the ruling elite to their own coffers. Taxes were reorganized. For the most part taxes remained at the same level, but in some cases revealed sharp increases to compensate for the declining revenue of the elite. More traumatic, however, was the move to collect tax in cash not grain; effected by 1910, not only did this undermine the zakkat based grain reserve but determined the penetration of a generalized modern currency into indigenous economic systems. Furthermore, taxation had profound and direct implications for hunger itself. First, unlike the indigenous Hausa fiscal system, colonial taxes were regular, reasonably predictable and rigid. The inflexibility accordingly took no account of the realities of Hausa life; late rains, poor harvests, seasonal hunger, and a precarious environment subject to perturbations such as locust invasion or epidemics. The severity of colonial taxation contrasted sharply with an indigenous system which, though far from innocent of extortion, made an attempt to graduate taxes according to existential circumstances. Second, the timing of tax collection assumed a colossal importance. This was especially the case throughout the principal cotton-growing areas, where annual taxes were gathered prior to the cotton harvest, leaving a rural cultivator little choice but the sale of grains when prices were the lowest or, alternatively, the moneylender. And third, the taxation system was inseparable from the colonial policy of the extension of commodity production and cash cropping into the countryside. In northern Hausaland groundnuts were the principal tax-paying crop which goes a long way in explaining the apparently "irrational" behavior of a peasantry which produced more groundnuts when the commodity price fell. More generally, the "groundnut revolution," particularly in the close-settled zoned, meant a decrease in the area devoted to foodstuffs, increasing subjection to the vagaries of the world commodity market and the ever present threat of indebtedness at the hands of middlemen. It is precisely in this way that the nature of seasonal hunger changes both in terms of its dynamics and the predicament of those who find themselves suffering from its effects. The net result tended to be that seasonal hunger developed into full-fledged famine, precipitated by a drought-induced harvest shortfall, as in 1913-14.

Despite the commercial setback of the 1913-14 famine, the groundnut revolution picked up momentum and became emblematic of the subsequent expansion in the produce trade. Through this process of commoditization, in which money acquired an increasingly important role, it is hardly surprising that new forms of indebtedness arose, especially through the 'yan baranda system. The 'yan baranda constituted the lower orders of the export crop buying hierarchy, receiving cash advances from European forms via their buying agents. These sums were in turn lent directly to the producer who pledged his crop to the agent. The interest on such loans was frequently in the order of $100 \%$ and for the producer at least was the initial step into a cyclical debt trap. Urban and merchant capital penetrated the countryside in this 
way. This also illuminates how a domestic unit is drawn into an external merchant network. [...]

The deepening involvement with commodity production and cash crops naturally impinged upon the social organization of agricultural production itself. [...] in the groundnut zone of Niger, this has taken the form of the disillusion of traditional estates, an escalation in land sales and the generalization of hired farm labor. Changes in the sociology of production were coupled with the profusion of imported commodities especially cloth which articulated with the cycle of rapidly inflation prices for ceremonial exchanges on the one hand, and the chain of indebtedness on the other. Stresses consequently were imposed upon the corporateness of the rural world; the old responsibilities and obligation became less binding, communal work groups largely disappeared and the extended family became less embracing and hence increasingly incapable of buffering individuals in crisis. In the densely settled areas, the extreme food shortages heralded larger food deficits and heightened vulnerability to seasonality. The household showed the first signs of fission and collective security had lost its original meaning; the old universe no longer possessed its intrinsic reality; social and familial solidarity appeared to be dissolving and the gift lost its original significance. [...] Reciprocity and solidarity and hence the nature of inequality itself had changed.

The general point is that post-1903, the margin of security for the Hausa peasantry came under siege. The Colonial Administration, only too aware of the dangers of over concentration on cash crop commodities, [...] overestimated the resiliency of the peasantry. The outcome was, in contrast to the previous century, that Hausaland suffered three major famines in 1913-14, 1927 (1931 in much of Niger) and 1942. Climatic variability became less crucial in the actual genesis of food shortage. This reached its apotheosis during the early 1940s with a famine whose structural properties bore a striking resemblance to the Bengal famine of 1943.

Hopefully, I have managed to convey the dynamics and historically contingent character of disasters such as famines, and hence how fallacious it would be to assume that hunger is simply an outcome of [population growth] or of a malevolent environment. The genesis of hunger and the etiology of peasant vulnerability in Hausaland [are] indeed complex. But the point is that merchant capital and the colonial state broke the cycle of reproduction of peasant households. The reproduction of the Hausa farming family became contingent upon the continued production of export commodities [...]. The need for cash ensured a greater devotion to cash crops on the part of the rural poor in the merchant-credit system. Falling export prices were experienced by households as a deterioration in the terms of exchange which meant either a reduction in levels of consumption or an intensification of commodity production or both. This has been referred to as "the simple reproduction squeeze" and is one facet of what Scott (1976) called the "margin of subsistence security." As even larger areas were devoted to cash crop production at the expense of foodstuffs (this was especially pernicious for the rural poor cultivating small holdings and 
experiencing severe labor constraints) the reproduction squeeze deepened and both hunger and indebtedness assumed increasing importance. [...] Hausa peasant producers thus became increasingly vulnerable to even small variations in income; the margin of subsistence security had been eroded. Indeed, the rural poor were vulnerable to any sort of perturbation and, under conditions of agricultural stagnation characteristic of the colonial period, Northern Nigerian producers were particularly susceptible to the usual environmental variability typical of the northern savannas. The rural poor were hyper-vulnerable for they succumbed to relatively slight oscillations in harvest quality; a light harvest could herald a subsistence crisis of famine proportions particularly if prevailing crop prices tended to be unfavorable. As one district officer noted, the Hausa peasantry lived constantly in the shadow of famine.

\section{Conclusion}

The fundamental material contradiction about which much resistance centered was the simple reproduction squeeze. In the cycle of household economy this was given effect as the struggle to secure simple reproduction under deteriorating conditions of production or exchange. The historical engagement of state and peasantry, in other words, hinged on the conditions of their reproduction. For rural producers, colonial incorporation ruptured the household cycle in which commodity production subsequently became "internalized." Commoditization actually proceeded along three fronts, the conversion of the products of surplus peasant labor into commodities, the conversion of the means of production into commodities, and the transformation of labor itself into a commodity. But the unevenness of capitalist penetration meant that these processes expanded differentially; not all households adopted export crops, not all males migrated to the mines, and only some profited from commerce. The result was a highly heterogeneous matrix of rural labor situations predicated on different commoditization. Distilling this heterogeneity to manageable proportions reveals that the expansion of commodity production was undertaken by a broad stratum of a middle peasantry, for whom more and more of household labor time was directed to commodity production. If they avoided the hardships of labor migration, the middle peasants were irregularly dependent on the market for subsistence. In addition, a phalanx of the rural poor secured simple reproduction only through the sale of their labor power, in the dry season of their wealthier brethren. Some eked a living from low-return crafts and petty trade. At any rate, among these quasi-proletarianized class a large proportion, perhaps 30-50 percent, of subsistence needs were met through purchase. And finally, a stratum of well-to-do farmer-traders developed, who probably devotes a greater proportion of their holdings to export commodities but still remained largely self-sufficient in food. They were deeply engaged in trade and, in a general sense, acted as agents of commodity relations. In all of this, monetization (which was a necessary corollary of generalized commodity production) provided a fertile ground for the proliferation of the credit mechanism that allowed merchant capital to exercise indirect control over production. 
I have argued that commoditization had profound implications for food security and famine. In an aggregate sense, food production per capita declined and many rural producers confronted annual grain purchase to fulfill an irreducible domestic demand. These periods of grain shortage corresponded to those in which preseason loans were distributed. Further, harvest shortfall or price fluctuations were felt as household crisis, which can lead to an intensification of the cycle of indebtedness. As Marx observed, the mere death of a cow might render the small peasant incapable of renewing his production. The intensification of commodity production subjected the rural poor to "all the horrors of producing for an increasingly demanding market and none of the benefits of capitalism over the other modes of production." At best, local shortage was an annual occurrence.

The changed conditions of peasant reproduction also peeled away the tissues of a moral economy. Commodity production and the participation in market relations had individuated household production, but the agency of the colonial state was also critical. New systems of administration, improved communications, and the bureaucratic question of a centralized state enhanced effective control over elites and peasant alike. [...] Taxes were seen by the peasantry (with good reason) as a loss of their rights. Even a low assessment by colonial reckoning far exceeded the flexible and customary exactions of the precolonial period. In short, incorporative process bred a sort of endemic vulnerability among a large segment of rural producers who, to use Marx's phrase, has increasingly come to live a "vegetable existence." [...]

The progressive incorporation of areas like northern Nigeria into a world economy altered the face of famine itself. It had the contradictory effect of rendering grain available in the marketplace but without sufficient means to produce it. Those who came to regularly depend on grain purchase were necessarily vulnerable to a volatile grain trade sustained by the regularity of regional and local deficits. More generally, the partial transformation of Hausa peasants made them vulnerable to capitalist market crisis, and also subject to the precapitalist limitations of the selective development of the means and forces of production. The intervention by the colonial state through relief, in a situation in large measure of its own making, was ineffective. In part this reflected the sheer magnitude of the problem, the mathematics of the gross numbers at risk; in part, it also presented a misconception of the etiology of the problem (peasant lethargy or overpopulation) and the bureaucratic incompetency of a sometimes comatose administration. But it was also not in the material interest of the state to regulate the merchant relationships upon which it was also dependent. Here lay the root of the contradiction between state and peasantry.

The political economy of colonialism in northern Nigeria was [...] a preindustrial combination of indigenous smallholders and large European trading monopolies. As in all state systems in which a good deal of revenue came from the

\footnotetext{
${ }^{6}$ Editors' note: reference missing in original
} 
land because the majority of people lived there, the maintenance of centralized political control in Nigeria was invariably problematic. The advent of modern transportation alleviated this somewhat, but such a decentralized system necessarily meant a good deal of local revenue leakage and difficulties of labor control. Up to a point, then, the peasant had an exit option. But I have shown that the deepening of commodity relations indeed limited the extent to which the peasant could either revert to subsistence production or lessen the effects of over-production of export commodities in the face of a volatile climate. The colonial state was instrumental in the proliferation of commodity production. Yet like all states, the colonial state in Nigeria confronted the possibility of fiscal and legitimation crisis. Ironically in its attempt to deepen commodity relations through taxation, monetization, and local merchant capital it often eroded its own fiscal and political stability. Famines in this regard were not only crisis of production but were equally seen as consumption crisis - in particular the market for European manufactures was reduced - and directed threats to political legitimacy. [...] I have argued conversely that the retarded form of capitalist development in Nigeria blocked any form of accumulation based on increased rural productivity and a transformation of the forces of production. Furthermore, commoditization weakened in a variety of ways the position of rural producers in the face of harvest variability. The colonial state was again critical in this process of siphoning peasant labor largely through absolute surplus extraction. Yet there were obvious limits to this system as the famines testify. Under these circumstances the state did indeed intervene with relief to regularize supply, but I have attempted to show the magnitude of the problem was far beyond the means of the colonial governments while the administrative incapacity of the state apparatus left rural producers with little but their poverty. [...] [T] here were no regularizing functions since expanded commodity production was achieved without raising peasant productivity and without a state capable of provisioning requisite food relief. As a result, the peasantry entirely shouldered the burden of famine. I would argue, however, that this can only be understood as a result of the contradiction between the stagnation of the productive forces and the development of productive relations, with the result that the form of production remains pre-capitalist while circuits of food - and social life in general became increasingly commoditized.

What emerges then, is that social crisis can be grounded in historical circumstances and used in such a way that additional insight can be gained into the process of underdevelopment. For Marx, the importance of a crisis lay, on the one hand, in exposing the contradictions inherent in that formation. In opposition to other analysts Marx saw crisis not as an aberration, but rather as an integral and necessary part of a given formation. In the pre-capitalist context, Marx identified crisis with the underproduction of use values; a period in which basic biological requirements could not be fulfilled as a result of drought, disease, extended periods of warfare or other similar causes. Pre-capitalist societies were vulnerable to the vicissitudes of nature as a consequence of the low level of development of their forces of production. Equally important, this low level of technical development could, particularly in a field such as 
transportation, severely limit the capacity of pre-capitalist societies to adequately overcome crisis resulting from natural calamities.

Conversely, in capitalist society Marx saw crisis as the result of an overproduction of exchange values. It is the surfeit rather than the lack of the necessities of life, and the inability of capitalist society to realize the value of these products, which leads to the economic depressions characteristic of the capitalist social formation. In contrast to the pre-capitalist situation it is the limited development of the relations of production which is responsible for the onset of a crisis. It is clear that the social formation of the Third World have not been solely constituted by either capitalist or pre-capitalist modes of production. Following the analysis of [Samir] Amin, the social formations of the Third World are more readily comprehended by the term "peripheral capitalism." Perhaps the single most important aspect of the development of the social formations of the peripheral capitalist world has been the selective transformation of their forces and relations of production. Two points follow from this perspective. First, only those sectors of pre-capitalist society which facilitated the extraction of a surplus were transformed. Second, the subsistence economy, although reoriented to satisfy the requirements of the extractive sector, remained virtually unchanged in terms of its forces of production.

Crises in the Third World can only be fully comprehended when they are situated within the social formation of peripheral capitalism. In other words, crises must be understood in terms of the varying extent to which pre-capitalist modes of production were either maintained or transformed by the manner in which they were incorporated into the capitalist world. The consequences of this view are important to an analysis of both the causes of and responses to crises in peripheral capitalist society. While peripheral capitalist societies become vulnerable to capitalist crises by virtue of their incorporation in the capitalist world economy, it is also the case that their partial transformation allows them to remain vulnerable to crises usually associated with precapitalist society. This contradiction is replicated when we examine the ability of peripheral capitalism to cope with, and respond to, crises. For while it is true that most pre-capitalist coping mechanisms have been lost, peripheral capitalism has been unable to acquire those capabilities characteristic of capitalism for mitigating natural disasters. Thus, crises in peripheral capitalism both illuminate the dynamics of, and expose the contradictions inherent in, the functioning of capitalism in the Third World. A study of crises can be seen, therefore, as the starting point of an analysis of the peripheral capitalist formations as a whole.

\section{References}

Bennet, J. 1976. The Ecological Transition. London: Pergamon.

Berg, E. 1975. The Recent Economic Evolution of the Sahel.. Ann Arbor: Centre for Research on Economic Development, University of Michigan. 
Brookfield, H. and A. Kirby. 1974. On Man, Environment and Change. IGU Workshop on Man-Environment Relations.

Clarke, W. 1977. The structure of permanence. In, T. Bayliss-Smith \& R. Feachem (eds.), Subsistence and Survival: Rural Ecology in the Pacific. San Francisco: Academic Press, pp. 363-84.

Cook, S. 1975. Production, ecology and economic anthropology. Social Science Information 12 (1), 41.

Cowen, M. 1976. Capital and household production in central province, Kenya. IDS Paper, Nairobi.

De Castro, J. 1975. The Geopolitics of Hunger. New York: Monthly Review.

Dyson-Hudson, N. 1976. Commentary. In, J. Newman (ed.), Drought, Famine and Population Movements in Africa. New York: Syracuse, p. 138.

Faulkingham, R. 1974. The demographic effects of drought in the West African Sahel. Unpublished manuscript.

Faulkingham, R. 1971. Political Support in a Hausa Village, Niger. Ph.D. dissertation, Michigan State University.

Freund, W. 1978. Oil boom and crisis in contemporary Nigeria. Review of African Political Economy 13, 91-100.

Freund, W. and R. Shenton. 1978. The incorporation of northern Nigeria into the world capitalist economy. Review of African Political Economy 13, 8-10.

Friedman, J. 1975. Tribes, states and transformations. In, M. Bloch (ed.), Marxist Analyses and Social Anthropology. London: ASA, pp. 161-202.

Geertz, C. 1967. Agricultural Involution. Berkeley: University of California Press.

Grossman, L. 1979. Cash, Cattle and Coffee in the Highlands of Papua New Guinea. Ph.D. dissertation, Australian National University.

Harriss, B. 1978. Going against the grain. Paper delivered to the IGU symposium on Market Exchange in Developing Countries, Zaria.

Hill, P. 1977. Population, Prosperity and Poverty: Rural Kano 1900-1970. London: Cambridge University Press.

Horowitz, M (ed.). 1976. Colloquium on the Effects of Drought on the Productive Strategies of Sudano-Sahelian Herdsmen and Farmers. New York: Institute for Development Anthropology. 
Kay, G. 1975. Development and Underdevelopment. London: MacMillan.

Lofchie, M. 1975. Political and economic origins of African hunger. Journal of Modern African Studies 13, 552.

McCay, B. and A. Vayda. 1977. Problems in the identification of environmental problems. In, T. Bayliss-Smith \& R. Feachem (eds.), Subsistence and Survival: Rural Ecology in the Pacific. San Francisco: Academic Press, pp. 411-8.

Mortimore, M. 1973. Famine in Hausaland. Savanna 2, 103-107.

Nicolas, G. 1966. Une forme attenuée du potlatch en pays Hausa: le dubu Cahiers de 1'ISEA. Économies et Sociétés V (10).

Nietschmann, B. 1973. Between Land and Water. San Francisco: Academic Press.

Oguntoyinbo, J. and P. Richards. 1977. The extent and intensity of the 1969-73 drought in Nigeria. In, D. Dalby \& R.J. Harrison Church (eds.), Drought in Africa II. London: IAI, pp. 114-26.

Popkin, S. 1979. The Rational Peasant. Berkeley: University of California Press.

Rapoport, A. and L. Slobodkin. 1974. An optimal strategy of evolution. Quarterly Review of Biology 49, 181-200.

Raulin, H. 1964. Techniques et Bases Socio-Économiques des Sociétés Rurales Nigeriennes. Études Nigerennes 12. Paris: CNRS.

Sawadago, P. 1975. Enquête sur les Nomads Refoules par la Sécheresse. Dakar: UNEP-IDEP.

Scott, J. 1976. The Moral Economy of the Peasant. New Haven: Yale University Press.

Seiffer, W. 1974. A Long Range Plan Defining Alternative Strategies for the Development of Sahel-Sudan Zones, 11 Volumes. Boston: Centre for Policy Alternatives, Massachusetts Institute of Technology.

Spitz, P. 1977. Silent Violence: Famine and Inequality. Geneva: UNRISD.

Stavenhagen, R. 1975. Agrarian Classes in Africa. New York: Avon.

Thompson, E. P. 1978. The Poverty of Theory. New York: Monthly Review.

Usman, Y. B. 1974. The Transformation of Katsina ca. 1796-1903. Ph.D. dissertation, Ahmadu Bello University, Zaria.

Walker, R. 1979. Introduction. Antipode 11, 7. 
Watts, M. 1979a. The etiology of hunger. Mass Emergencies 4, 95-104.

Watts, M. 1979b. A Silent Revolution: The Changing Character of Food Production and the Nature of Famine in Northern Nigeria. Ph.D. dissertation, University of Michigan.

Watts, M. 1978. The Food Crisis in the Sahel. Report prepared for the International Disasters Institute, London.

Wisner, B. 1978a. Does geography lack an approach to environmental relations? Antipode 10, 84-95.

Wisner, B. 1978b. The Human Ecology of Drought in Eastern Kenya. Ph.D. dissertation, Clark University. 